\title{
【Transaction】
}

\section{Effective Saccharification and Fermentation of Kraft Pulp to Produce Bioethanol}

\author{
Gulibusitan Aierkentai*1, Xianxiang Liang*1, Toshiyuki Uryu*1, and Takashi Yoshida*1,\# \\ ${ }^{*} 1$ Department of Bio and Environmental Chemistry, Kitami Institute of Technology, \\ 165 Koen-cho, Kitami, Hokkaido 090-8507, Japan
}

\begin{abstract}
Bioethanol was obtained from softwood bleached kraft pulp (NBKP), an intermediate product from industrial paper processes, by successive or simultaneous saccharification and fermentation. Saccharification of NBKP was performed with several cellulases, revealing that Cellic CTec2 cellulase was the most effective at saccharification and resulted in yield of $76.3 \%$ after $72 \mathrm{~h}$. Though X-ray measurements, it was noted that the crystallinity of NBKP decreased after alkali treatment with $9 \%$ sodium hydroxide $(\mathrm{NaOH})$ solution for 10 min at $-10^{\circ} \mathrm{C}$. Alkali-treatment also decreased the weight of NBKP by $5 \mathrm{wt} \%$. This was hypothesized to be due to removal of dissolved hemicellulose and lignin. Short time saccharification of alkali-treated NBKP resulted in good yields of glucose production and the yields did not increase with longer saccharification times. Successive saccharification and fermentation of untreated and alkali-treated NBKP were conducted using Cellic CTec2 (at 1:10 ratio by wt with respect to NBKP) for $72 \mathrm{~h}$ and then addition of a recombinant yeast (pYBGA 1 ) to give ethanol in $91.3 \%$ and $93.3 \%$ yields under the optimum conditions of cellulase and yeast, respectively, based on saccharified glucose. In contrast, simultaneous saccharification and fermentation could not effectively produce ethanol from NBKP, regardless of alkali-treatment; this may because of low efficiency of the saccharification. Using other combinations of cellulases and yeast strains to produce ethanol, it was found that Sucrase C, Meicelase, and Sumizyme C were also effective cellulases for the saccharification of alkali-treated NBKP. Furthermore pYBGA 1 was more effective at fermentation than yeast strain Kyokai No. 7 (K 7). Under optimized conditions for cellulase and recombinant yeast, ethanol yields were 91.3 and $93.3 \%$ for untreated and alkali-treated NBKP, respectively; these results show that a combination of Cellic CTec2 and pYBGA 1 was the most effective for the process of successive saccharification and fermentation of NBKP.
\end{abstract}

(Received 10 July, 2017; Accepted 7 August, 2017)

\section{Introduction}

Bioethanol synthesized from renewable resources such as biomass is expected to be a next-generation environment-friendly fuel that can be used to replace fossil fuels [1]. Bioethanol can be classified into two types, starch-based and cellulosic. Among them, starch can be enzymatically converted to glucose, which is then fermented to produce ethanol. However, ethanol production from starch would directly compete against available food resources. Therefore, inedible cellulose would be preferred as a renewable, low-cost material for bioethanol production despite its rigid crystalline structure that cannot be easily decomposed into glucose.
Many papers and methods on the preparation of bioethanol from cellulosic materials have been reported till date $[2,3]$. Tissue paper, cotton, and sawdust subjected first to a two-step sulfuric acid hydrolysis to produce cello-oligosaccharides before fermentation by pYBGA 1 , a recombinant yeast expressing $\beta$-glucosidase, could be used to produce ethanol at high yields [4]. Ethanol could be also produced at good yields by direct saccharification and fermentation of cello-oligosaccharides by pYBGA 1 [5]. This direct method of producing ethanol from cellooligosaccharides was a simple procedure that decreased time, costs, and energy consumption. In addition, ethanol could be produced from readily available agricultural residues, such as beet pulp and 
leaf, corn stover, and weed, via dilute alkali pretreatment, saccharification, and fermentation with pYBGA 1 at good yields [6].

Softwood bleached kraft pulp (NBKP) is an intermediate product from the industrial paper process and is produced when wood chips are treated with a mixture of sodium hydroxide and sodium sulfide, which can also be used to remove lignin. NBKP has higher cellulose content when compared with hardwood bleached kraft pulp (LBKP) [7]. Nakano reported the relationship between freeness and initial glucose yield by enzymatic saccharification of beaten NBKP and LBKP [8]. The glucose yield of NBKP was higher than that of LBKP when both kraft pulps had the same freeness. The saccharification should be dependent on the cellulose content in the kraft pulp. Several reports have described the synthesis of bioethanol from kraft pulp because the kraft process is an established industrial process for paper production. The effects of enzyme dosage on the conversion of NBKP to ethanol were also reported. A previous report detailing simultaneous saccharification and fermentation (SSF) of kraft pulp by using cellulases Novozyme Celluclast $1.5 \mathrm{~L}$ and Novozyme 188 at a combined weight percent of 33\%, and Saccharomyces cerevisiae or Candida molischiano expressing $\beta$-glucosidase, respectively, to produce ethanol at a yield of 67\% [9]. Another report on SSF of kraft pulp from Eucalyptus globulus used Novozyme 188 and S. cerevisiae to produce $0.26 \mathrm{~kg}$ of ethanol from $1 \mathrm{~kg}$ of starting material [10]. Simultaneous saccharification and co-fermentation (SSCF) of a kraft paper mill sludge using Spezyme CP cellulase and recombinant $E$. coli and $S$. cerevisiae, respectively, afforded higher ethanol yields of $75-81 \%$ than a SSF process using the same components (Spezyme CP cellulose, and recombinant $E$. coli and $S$. cerevisiae, respectively) [11].

Herein, we report a method for bioethanol production from untreated and alkali-treated NBKP via successive saccharification and fermentation (SUSF) using a combination of cellulases, and pYBGA1 or K 7 yeast. We found that the SUSF was the most effective approach for producing bioethanol from NBKP.

\section{Experimental Section}

\subsection{Materials}

NBKP was obtained from OmiKenshi Co. Ltd.,
Osaka, Japan. pYBGA 1 was a kind gift from the National Research Institute of Brewing (Higashi Hiroshima, Japan) [12] and was incubated on agarose medium according to previous instructions [5]. Japanese traditional alcohol (Sake) yeast strain Kyokai No. 7 (K7) was purchased from Seihin Kiko, Japan. Cellic CTec2 (1,000 EGU/g), Meicelase (400 FPU/g), Sucrase C (3,000 U/g), and Sumizyme C (1,500 U/g) cellulases were kind gifts from Novozymes Japan Ltd. Meiji Seika Pharma Co. Ltd., Mitsubishi-Kagaku Foods Corp., and Shin Nihon Chemical Co. Ltd., respectively. Yeast extract and peptone used were purchased from commercially available sources.

\subsection{Alkali-treated NBKP $[13,14]$}

$2.00 \mathrm{~g}$ of NBKP was shredded using scissors prior to the addition of $100 \mathrm{~mL}$ of $9 \mathrm{wt} \%$ sodium hydroxide $(\mathrm{NaOH})$ solution. After stirring for $10 \mathrm{~min}$ at $-10^{\circ} \mathrm{C}$, $100 \mathrm{~mL}$ of water was added to the mixture to precipitate the alkali-treated NBKP. These precipitates were washed with water several times, then dialyzed against water overnight, and dried to obtain $1.89 \mathrm{~g}$ of alkali-treated NBKP.

\subsection{Component analysis of NBKP [15]}

Water and ash contents of NBKP were measured using a thermogravimetric analysis (TGA) system. $8.22 \mathrm{mg}$ of NBKP was placed into the TGA system chamber under air atmosphere and then the temperature was raised to $110^{\circ} \mathrm{C}$ at the rate of $10^{\circ} \mathrm{C} / \mathrm{min}$. After $10 \mathrm{~min}$, the temperature increased to $550^{\circ} \mathrm{C}$ at the rate of $10^{\circ} \mathrm{C} / \mathrm{min}$ and held for $20 \mathrm{~min}$.

The content of cellulose, hemicelluloses, and lignin was determined using the method developed by the National Renewable Energy Laboratory (NREL). $300 \mathrm{mg}$ of NBKP was added to $3 \mathrm{~mL}$ of $72 \% \mathrm{v} / \mathrm{v}$ sulfuric acid aqueous solution in a sealed glass tube, which was then placed into a water bath at $30^{\circ} \mathrm{C}$. After $1 \mathrm{~h}$ of stirring, the sulfuric acid-NBKP mixture was diluted to $4 \% \mathrm{v} / \mathrm{v}$ by water and autoclaved for $1 \mathrm{~h}$ at $121^{\circ} \mathrm{C}$. To obtain lignin, the mixture was cooled to room temperature, filtered, dried, and weighed. The filtrate was measured for cellulose and hemicellulose content via HPLC analysis. The experiment was repeated five times, and means values are reported in Table 1.

\subsection{Saccharification}

A typical procedure for the saccharification by using Cellic CTec 2 is as follows. In a $300 \mathrm{~mL}$ Erlenmeyer flask containing the Kraft pulp (2.0 g) and deionized water (100 mL) was added to NBKP (2.0 g). The $\mathrm{pH}$ of the solution was adjusted at 4.5 by $5 \mathrm{wt} \%$ 
aqueous $\mathrm{HCl}$, and then Cellic CTec2 (10 wt\% to Kraft pulp) was added. The solution was stirred at $45^{\circ} \mathrm{C}$ in an oven. The saccharified glucose was sampled by using a syringe with a long needle every $12 \mathrm{~h}$. Alkalitreated Kraft pulp was also saccharified by the same manner. The results were listed in Table 2.

\subsection{Successive saccharification and fermentation (SUSF)}

SUSF of NBKP requires an additional fermentation step following the saccharification process described in Section 2.4. After $72 \mathrm{~h}$ of saccharification, the temperature of the solution decreased to $30^{\circ} \mathrm{C}$ for the addition of yeast extract $(10 \mathrm{~g} / \mathrm{L})$, peptone $(20 \mathrm{~g} / \mathrm{L})$, and pYBGA $1\left(1 \times 10^{8}\right.$ cells $/ \mathrm{mL}$ ). The fermentation continued for another 96 $\mathrm{h}$ with gentle stirring at $30^{\circ} \mathrm{C}$ and $\mathrm{pH} 5.0$ in an oven. Ethanol $(5.6 \mathrm{~g} / \mathrm{L})$ was obtained at a $90.6 \%$ yield based on the amount of saccharified glucose after fermentation for $24 \mathrm{~h}$. The SUSF of alkali-treated NBKP also proceeded in same manner as that of NBKP.

\subsection{Simultaneous saccharification and fermentation (SSF)}

SSF of NBKP involves the saccharification step described in Section 2.4 to be performed at $30^{\circ} \mathrm{C}$, instead of $45^{\circ} \mathrm{C}$, in conjunction with the fermentation step by simply mixing in Cellic CTec2 (10 wt\% to NBKP), pYBGA $1\left(1 \times 10^{8}\right.$ cells $\left./ \mathrm{mL}\right)$, yeast extract $(10 \mathrm{~g} / \mathrm{L})$, and peptone $(20 \mathrm{~g} / \mathrm{L})$. SSF proceeded at $30^{\circ} \mathrm{C}$ in an oven with gentle stirring using a rotary shaker for a total of $96 \mathrm{~h}$, and samples were obtained using a syringe every $6 \mathrm{~h}$ or $12 \mathrm{~h}$ to measure the concentrations of glucose and ethanol (Tables 5 and 6 , respectively).

\subsection{Measurement}

TGA was performed using a DTG-60 (SHIMADZU), as described in Section 2.3. Water and ash contents of
NBKP were measured at $110^{\circ} \mathrm{C}$ and $550^{\circ} \mathrm{C}$, respectively. Sugars produced by saccharification were determined using an aqueous HPLC system with a Tosoh TSK-gel amide-80 column $(5 \mu \mathrm{m}, 4.6 \mathrm{~mm}$ $\times 250 \mathrm{~mm}$ ) with a solution of $50 \%$ acetonitrile in water as the mobile phase at a flow rate of $0.5 \mathrm{~mL} / \mathrm{min}$. Standard glucose solutions were used for calibration. Ethanol concentration was determined, under a nitrogen atmosphere, using a Shimadzu GC-8A gas chromatograph with a capillary column (SE-30, $3.2 \mathrm{~mm} \times 30 \mathrm{~m})$ and a hydrogen flame ionization detector. The column and injection temperatures were at $60^{\circ} \mathrm{C}$ and $130^{\circ} \mathrm{C}$, respectively.

\section{Results and discussion}

\subsection{Component analysis of NBKP}

The contents of NBKP were determined via TGA for water and ash, and the NREL method for cellulose, hemicellulose, and lignin [15]. Table 1 shows the results of the component analysis of NBKP and is also listed some reported data. The cellulose content in NBKP was $88.3 \%$, which is slightly higher than that of the reported data [15-17] and may be because NBKP inherently has a relatively higher content of cellulose. Figure 1 indicates the TGA profile of (A) NBKP and (B) alkali-treated NBKP, in which water and ash contents were measured at $110^{\circ} \mathrm{C}$ and $550^{\circ} \mathrm{C}$ to be $5.1 \mathrm{wt} \%$ and $1.6 \mathrm{wt} \%$ (No. 1 in Table 1), respectively.

\subsection{Alkali treatment of NBKP}

NBKP was treated with $9 \% \mathrm{NaOH}$ solution to decrease the degree of crystallinity; it is known that the crystalline structures of cellulose and NBKP, which mostly comprises cellulose, is resistant to enzymatic saccharification [13, 14]. Alkali-treated NBKP had a slightly decreased weight, $1.89 \mathrm{~g}$, compared to the original weight of $2.00 \mathrm{~g}$, increased

Table 1 Component analysis of Kraft pulp by NREL method ${ }^{a}$

\begin{tabular}{|c|c|c|c|c|c|c|}
\hline No & $\begin{array}{l}\text { Alkali } \\
\text { treatment }\end{array}$ & $\begin{array}{c}\text { Cellulose } \\
\text { wt } \%\end{array}$ & $\begin{array}{l}\text { Hemicellulose } \\
\text { wt } \%\end{array}$ & $\begin{array}{l}\text { Lignin } \\
\mathrm{wt} \%\end{array}$ & $\begin{array}{l}\text { Ash } \\
w t \%\end{array}$ & $\begin{array}{l}\text { Water } \\
\text { wt } \%\end{array}$ \\
\hline 1 & - & 88.3 & 1.7 & 2.0 & 5.1 & 1.6 \\
\hline $2^{b}$ & o & 90.5 & 1.3 & 1.0 & 5.0 & 0.6 \\
\hline $3^{c}$ & - & 84.3 & 3.9 & 7 & ${ }_{-}^{\mathrm{d}}$ & $-{ }^{d}$ \\
\hline $4^{c}$ & - & 76.7 & 7.7 & 3.2 & $\mathrm{~d}^{\mathrm{d}}$ & $-^{d}$ \\
\hline $5^{c}$ & - & 83.4 & 8.9 & 3.8 & $\mathrm{~d}^{\mathrm{d}}$ & $-{ }_{-}^{d}$ \\
\hline
\end{tabular}

a) Analysis was performed according to the NERL protocol [15].

b) Alkali treatment of NBKP was carried out with $9 \% \mathrm{NaOH}$ solution for $10 \mathrm{~min}$ at $-10^{\circ} \mathrm{C}$ according to the literature $[13,14]$.

c) From literatures, [16], [17], and [18], respectively.

d) No information. 


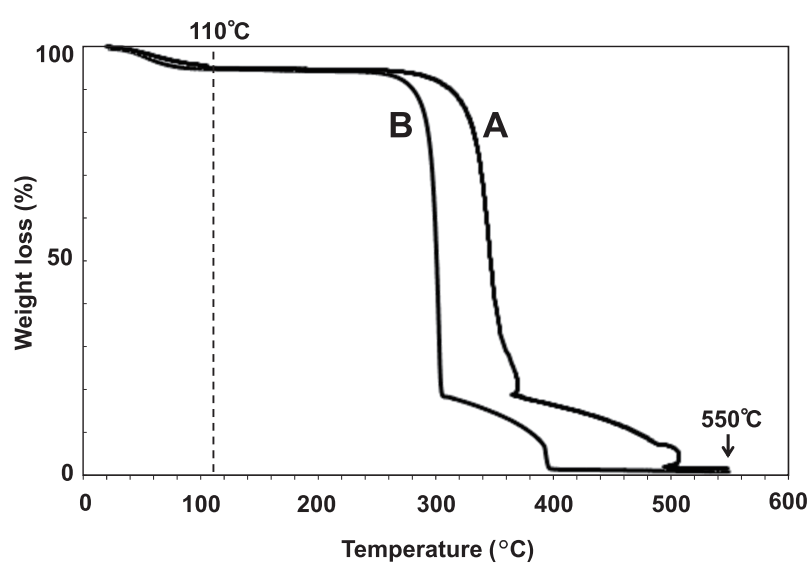

Fig. 1 Thermogravimetric analysis of dried (A) NBKP and (B) alkali-treated NBKP on the first heating run $\left(10^{\circ} \mathrm{C} / \mathrm{min}\right)$ under $\mathrm{N}_{2}$.

The heating was kept for $10 \mathrm{~min}$ at $110^{\circ} \mathrm{C}$ and $550^{\circ} \mathrm{C}$, respectively. Water and ash contents of (A) NBKP and (B) alkali-treated NBKP were $5.1 \%$ and $1.6 \%$, and $5.0 \%$ and $0.6 \%$, respectively. The alkali treatment of NBKP was performed with $9 \% \mathrm{NaOH}$ solution for $10 \mathrm{~min}$ at $-10^{\circ} \mathrm{C}$.

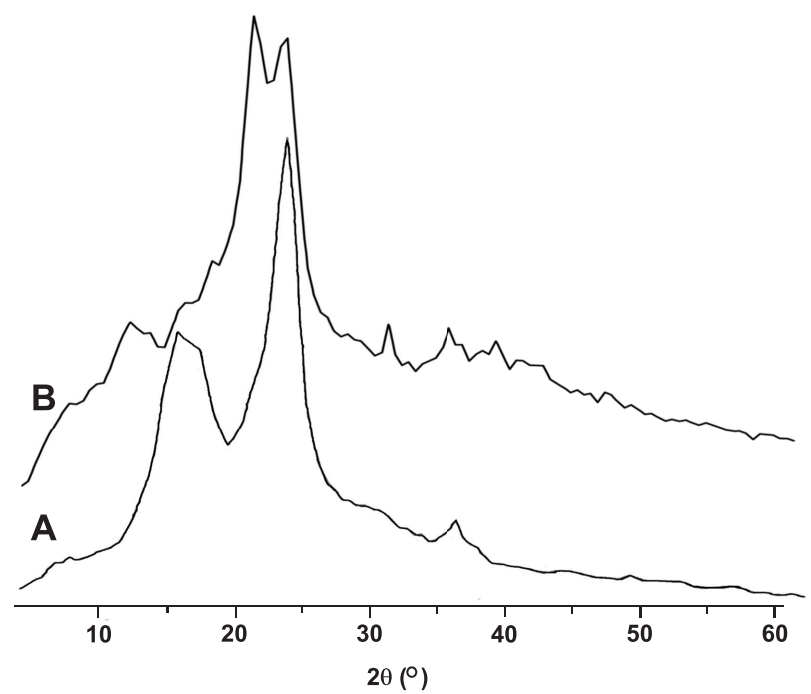

Fig. 2 X-ray profiles of NBKP before (A) and after (B) alkali treatment. The degree of crystallinity of (A) NBKP was calculated to be 0.62 according to Wuorinrn and Vianpaa's method [19].

cellulose content, and decreased hemicellulose and lignin contents as shown in Table 1. These results suggest that hemicellulose and lignin were removed via the alkali treatment. Water and ash contents were $5.0 \mathrm{wt} \%$ and $0.6 \mathrm{wt} \%$ (No. 2 in Table 1), respectively.

The degree of crystallinity was measured using X-ray as shown in Figure 2. Before alkali treatment (Figure 2A), NBKP had the same cellulose I structure as microcrystalline cellulose, and the degree of crystallinity was calculated to be 0.62 according to the method of Wuorinen and Vianpaa [19]. After alkali treatment (Figure 2B), it was found that the crystalline structure was changed into cellulose II [14], indicating that enzymatic saccharification should proceed more easily in comparison with untreated NBKP. The degree of crystallinity of alkali-treated NBKP could not be measured by Wuorinen and Vianpaa's method [19], because this method is for only cellulose I. In addition, FT-IR of NBKP and alkalitreated NBKP was measured and the spectra were compared to that of microcrystalline cellulose as shown in Figure 3. The intensity of $1100 \mathrm{~cm}^{-1}$ signal due to $\mathrm{OH}$ association on hydrogen bonds decreased [14], indicating that the intra- and intermolecular hydrogen bonds of cellulose molecule in NBKP was destroyed by the alkali treatment.

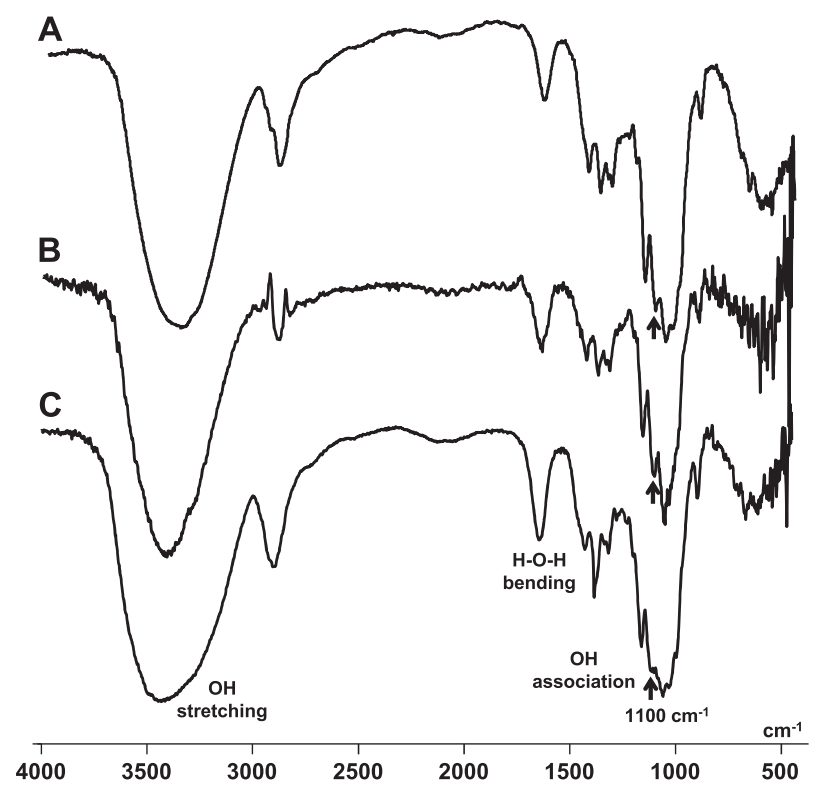

Fig. 3 FT-IR spectra of (A) microcrystalline cellulose, (B) NBKP, (C) alkali-treated NBKP by a $\mathrm{KBr}$ pellet method. The signal at $1100 \mathrm{~cm}^{-1}$ should be $\mathrm{OH}$ association signal due to intra- and intermolecular hydrogen bonds in cellulose molecule.

\subsection{Saccharification of NBKP}

Saccharification of untreated and alkali-treated NBKP was performed using several cellulases at 5 to $15 \mathrm{wt} \%$ of the starting amount of NBKP. The results are summarized in Table 2. As shown in No. 3, for $24 \mathrm{~h}$ saccharification of untreated NBKP at $10 \mathrm{wt} \%$ (compared to NBKP) of Cellic CTec2, glucose was produced at a yield of $55.4 \%$ based on the starting amount of cellulose. In contrast, the saccharification of alkali-treated NBKP occurred at a faster rate than that of untreated NBKP and produced glucose at a yield of $63.7 \%$ after only $12 \mathrm{~h}$. However, the saccharification was incomplete for the short time. After long-time saccharification, as shown in No. 4, the glucose conversion of alkali-treated and untreated 
Table 2 Saccharification of NBKP and alkali-treated NBKP

\begin{tabular}{|c|c|c|c|c|c|c|c|c|c|c|}
\hline \multirow[b]{2}{*}{ No. } & \multirow[b]{2}{*}{ Cellulase } & & \multirow[b]{2}{*}{$\mathrm{pH}$} & \multirow[b]{2}{*}{$\begin{array}{c}\text { Temp } \\
{ }^{\circ} \mathrm{C}\end{array}$} & \multicolumn{3}{|c|}{ NBKP } & \multicolumn{3}{|c|}{ Alkali-treated NBKP ${ }^{b}$} \\
\hline & & $\mathrm{wt} \%$ & & & $\begin{array}{c}\text { Time } \\
\mathrm{h}\end{array}$ & $\begin{array}{c}\text { Sugar } \\
\mathrm{g} / \mathrm{L}\end{array}$ & $\begin{array}{c}\text { Yield } \\
\%\end{array}$ & $\underset{h}{\text { Time }}$ & $\begin{array}{c}\text { Sugar } \\
\mathrm{g} / \mathrm{L}\end{array}$ & $\begin{array}{c}\text { Yield } \\
\%\end{array}$ \\
\hline 1 & Cellic CTec2 & 5 & 4.5 & 45 & 24 & 2.4 & 13.6 & 24 & 6.30 & 36.8 \\
\hline 2 & & & & & 72 & 4.0 & 22.6 & 72 & 5.91 & 34.6 \\
\hline 3 & & 10 & 4.5 & 45 & 24 & 9.8 & 55.4 & 12 & 10.9 & 63.7 \\
\hline 4 & & & & & 72 & 13.5 & 76.3 & 81 & 12.8 & 74.9 \\
\hline 5 & & 15 & 4.5 & 45 & 24 & 9.7 & 54.8 & 24 & 12.0 & 66.8 \\
\hline 6 & & & & & 72 & 12.5 & 70.8 & 81 & 13.9 & 81.3 \\
\hline 7 & Meicelase & 5 & 4.5 & 45 & 24 & 8.5 & 48.0 & 24 & 7.05 & 41.2 \\
\hline 8 & & & & & 72 & 10.2 & 57.6 & 72 & 8.29 & 48.5 \\
\hline 9 & & 10 & 4.5 & 45 & 24 & 10.0 & 56.5 & 24 & 10.8 & 63.2 \\
\hline 10 & & & & & 72 & 12.3 & 69.5 & 81 & 10.6 & 62.0 \\
\hline 11 & & 15 & 4.5 & 45 & 24 & 9.7 & 54.8 & 24 & 11.6 & 67.8 \\
\hline 12 & & & & & 72 & 11.2 & 63.6 & 81 & 15.7 & 91.8 \\
\hline 13 & Sucrase C & 5 & 5.0 & 60 & 24 & 2.2 & 12.4 & 24 & 4.12 & 24.1 \\
\hline 14 & & & & & 72 & 3.5 & 19.8 & 72 & 6.4 & 37.4 \\
\hline 15 & & 10 & 5.0 & 60 & 24 & 4.6 & 26.0 & 24 & 6.8 & 39.8 \\
\hline 16 & & & & & 72 & 4.2 & 23.7 & 81 & 10.4 & 60.2 \\
\hline 17 & & 15 & 5.0 & 60 & 24 & 8.8 & 49.7 & 24 & 9.6 & 56.1 \\
\hline 18 & & & & & 72 & 10.0 & 56.5 & 81 & 15.0 & 87.8 \\
\hline 19 & Sumizyme C & 5 & 4.5 & 60 & 24 & 1.9 & 10.7 & 24 & 4.41 & 25.8 \\
\hline 20 & & & & & 72 & 2.3 & 13.0 & 72 & 2.3 & 13.3 \\
\hline 21 & & 10 & 4.5 & 50 & 24 & 5.1 & 28.8 & 24 & 6.6 & 38.6 \\
\hline 22 & & & & & 72 & 5.0 & 28.2 & 81 & 10.0 & 58.5 \\
\hline 23 & & 15 & 4.5 & 50 & 24 & 5.3 & 29.9 & 24 & 9.0 & 52.6 \\
\hline 24 & & & & & 72 & 8.2 & 46.3 & 81 & 12.9 & 75.4 \\
\hline 25 & T Amano 4 & 10 & 4.5 & 45 & 72 & 2.7 & 15.3 & & & \\
\hline 26 & Sumizyme AC & 10 & 4.5 & 45 & 96 & 2.6 & 14.7 & & & \\
\hline 27 & H Amano 90 & 10 & 4.5 & 45 & 96 & 2.1 & 11.8 & & & \\
\hline 28 & CellicHtec2 & 10 & 4.5 & 45 & 96 & 1.1 & 6.2 & & & \\
\hline
\end{tabular}

NBKP increased with similar yields of $76.3 \%$ and $74.9 \%$, respectively, probably because Cellic CTec2 cellulase may have a high ability to saccharify crystalline cellulose. For untreated NBKP with 15 wt\% Cellic CTec2, glucose was obtained at a yield of $70.8 \%$ (No. 6). Although the yield of glucose decreased slightly in comparison with that in No. 4, the reason is under investigated. Regardless, at short time scales, saccharification of alkali-treated NBKP was faster than that of untreated NBKP, which was hypothesized to be due to changes in the crystalline structure of cellulose as a result of alkali treatment (Figure 3). For long saccharification times, no differences between untreated and alkali-treated NBKP were observed on the quantity of cellulase and the yield of glucose. Other cellulases were tested for the saccharification process. Meicelase had high ability to saccharify untreated NBKP, while Sucrase C and Sumizyme C cellulases could easily saccharify alkali-treated NBKP in comparison to untreated NBKP. It was also found that the functionality of cellulases for saccharification was different depending on the type of cellulose. For example, Hemicellulases, TAmano 4, Sumizyme AC, HAmano 90, and Cellic HTech 2 had lower conversions of NBKP to glucose.

\subsection{Successive saccharification and fermentation (SUSF)}

Scheme 1 shows the enzymatic saccharification and fermentation of NBKP to ethanol. Bioethanol was obtained using two methods: SUSF and SSF by using several cellulases and pYBGA1 or K7 yeast. The SUSF method has two successive steps: first, saccharification performed using cellulases at the optimum $\mathrm{pH}$ and temperature of the enzyme, and then fermentation proceeds with the addition of yeast at the optimum $\mathrm{pH}$ and temperature of the organism. The SSF method combined the saccharification and fermentation steps to proceed simultaneously at the optimum $\mathrm{pH}$ and temperature of yeast. The SUSF method required more time than the SSF method but resulted in improved conversion yields of NBKP to

(1) Simultaneous saccharification and fermentation

Enzymatic saccharification at $30^{\circ} \mathrm{C}$

NBKP $\underset{\text { Fermentation at } 30^{\circ} \mathrm{C} \text { and } \mathrm{pH} 4.5-5.0}{\longrightarrow}$ Ethanol

(2) Successive saccharification and fermentation

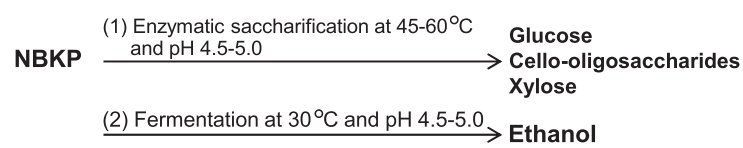

Scheme 1 Enzymatic saccharification and fermentation of kraft pulp (NBKP) to ethanol 

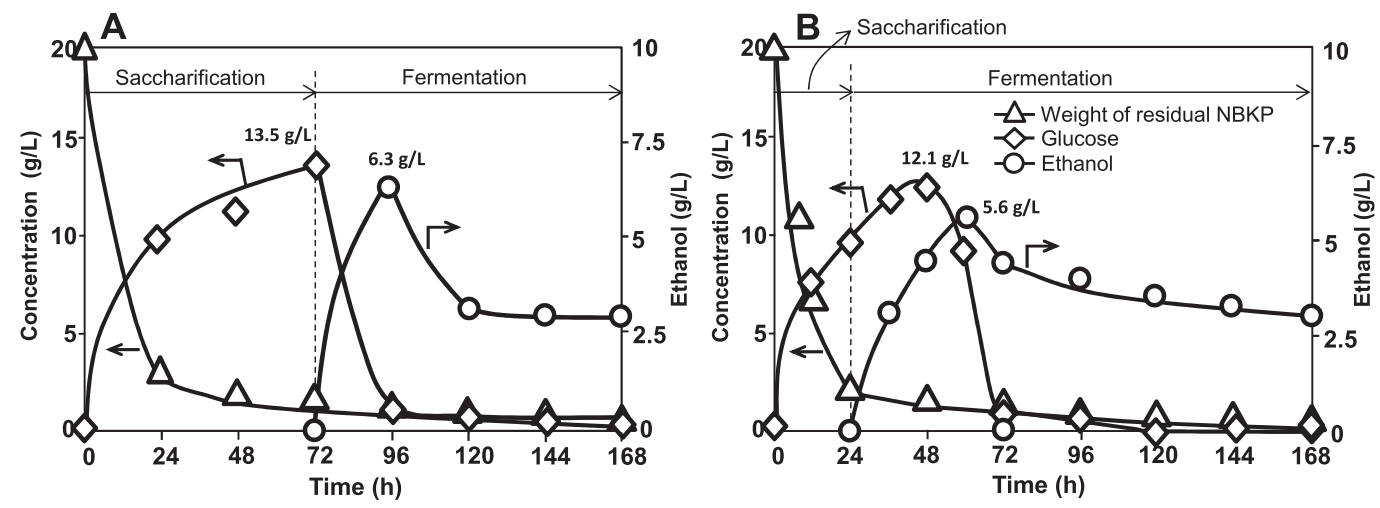

Fig. 4 Time course of successive saccharification and fermentation of (A) NBKP and (B) alkalitreated NBKP with Cellic CTec2 (10 wt\% to NBKP) as cellulase and $1 \times 10^{8}$ cells $/ \mathrm{mL}$ of pYBGA 1 yeast. The saccharification was for (A) $72 \mathrm{~h}$ and (B) $24 \mathrm{~h}$, respectively, at $45^{\circ} \mathrm{C}$ and $\mathrm{pH} 4.5$, and then fermentation was started by addition of pYBGA1 yeast, yeast extract, and peptone at $30^{\circ} \mathrm{C}$ and $\mathrm{pH} 5.0$.

ethanol.

Figure 4 indicates the result of the successive saccharification and fermentation (SUSF) of NBKP. The SUSF of untreated NBKP was performed using Cellic CTec2 as a cellulase and pYBGA 1 . As shown in Figure $4 \mathrm{~A}$, after saccharification of $20 \mathrm{~g} / \mathrm{L}$ of NBKP with $10 \mathrm{wt} \%$ cellulase for $72 \mathrm{~h}$ at $55^{\circ} \mathrm{C}$ and at a pH of 5.0, the resulting precipitate of NBKP disappeared and the concentration of glucose increased gradually to $13.5 \mathrm{~g} / \mathrm{L}$. The temperature of the solution was decreased to $30^{\circ} \mathrm{C}$ and the $\mathrm{pH}$ was adjusted to 4.5 to obtain the optimum fermentation conditions of pYBGA 1 , which was then added to the solution at $1 \times$ $10^{8}$ cells $/ \mathrm{mL}$. After $24 \mathrm{~h}$ of fermentation, $6.3 \mathrm{~g} / \mathrm{L}$ of ethanol was produced at a yield of $91.3 \%$ from saccharified glucose. Fermentation then continued for another $72 \mathrm{~h}$, but the ethanol concentration decreased to $2.6 \mathrm{~g} / \mathrm{L}$. This may be because pYBGA 1 can consume ethanol as a carbon source [4]. Figure $4 \mathrm{~B}$ also shows the SUSF of alkali- treated NBKP. After $24 \mathrm{~h}$ saccharification with Cellic CTec2 cellulase, pYBGA 1 yeast was added. Saccharification time was reduced to $24 \mathrm{~h}$ from $72 \mathrm{~h}$ for rapid saccharification. For the initial $24 \mathrm{~h}$ of fermentation at $30^{\circ} \mathrm{C}$ and $\mathrm{pH} 5.0$, glucose concentration increased and then decreased, probably because the saccharification of the remained NBKP continued by Cellic CTec2 cellulase. Addition of pYBGA 1 yeast at $24 \mathrm{~h}$ saccharification gave in a lower amount of ethanol, which decreased to $5.6 \mathrm{~g} / \mathrm{L}$ from $6.3 \mathrm{~g} / \mathrm{L}$ (Figure $4 \mathrm{~A}$ ). A reason for the lower conversion value could be the incomplete saccharification of NBKP due to a shorter saccharification time and under unsuitable saccharification conditions for Cellic CTec2 cellulase.

Table 3 shows the results of the SUSF method of NBKP. It should be noted that Cellic CTec2 cellulase

Table 3 Successive saccharification and fermentation of NBKP with cellulases and yeasts

\begin{tabular}{|c|c|c|c|c|c|c|c|c|c|c|c|c|c|c|c|}
\hline \multirow[t]{4}{*}{ No } & \multicolumn{5}{|c|}{ Saccharification } & \multicolumn{10}{|c|}{ Fermentation } \\
\hline & & & \multirow{3}{*}{$\mathrm{pH}$} & \multirow{3}{*}{$\begin{array}{c}\text { Temp } \\
{ }^{\circ} \mathrm{C}\end{array}$} & \multirow{3}{*}{$\begin{array}{c}\text { Time }^{b} \\
\mathrm{~h}\end{array}$} & \multicolumn{5}{|c|}{ pYBGA1 } & \multicolumn{5}{|c|}{ K7 } \\
\hline & \multicolumn{2}{|c|}{ Cellulase } & & & & Sugar & Time $^{c}$ & Ethanol & Yield $^{\mathrm{d}}$ & Yield $^{\mathrm{e}}$ & Sugar & Time & Ethanol & Yield $^{\mathrm{d}}$ & Yield $^{\mathrm{e}}$ \\
\hline & & $w t \%$ & & & & $\mathrm{~g} / \mathrm{L}$ & $\mathrm{h}$ & $\mathrm{g} / \mathrm{L}$ & $\%$ & $\%$ & $\mathrm{~g} / \mathrm{L}$ & $\mathrm{h}$ & $\mathrm{g} / \mathrm{L}$ & $\%$ & $\%$ \\
\hline 1 & Cellic CTec2 & 10 & 4.5 & 45 & 72 & 13.5 & 24 & 6.3 & 69.6 & 91.3 & 12.0 & 24 & 5.0 & 55.2 & 81.6 \\
\hline 2 & Cellic CTec2 & 10 & 4.5 & 45 & 24 & $12.1^{\mathrm{f}}$ & 36 & 5.6 & 61.9 & 90.6 & & & & & \\
\hline 3 & Cellic CTec2 & 15 & 4.5 & 45 & 72 & 11.2 & 24 & 4.9 & 54.1 & 85.7 & & & & & \\
\hline 4 & Meicelase & 10 & 4.5 & 45 & 72 & 13.0 & 48 & 5.5 & 60.8 & 83.4 & 12.3 & 48 & 4.3 & 47.5 & 68.5 \\
\hline 5 & Meicelase & 15 & 4.5 & 45 & 72 & 11.2 & 24 & 4.4 & 48.6 & 76.9 & & & & & \\
\hline 6 & Sucrase C & 10 & 5.0 & 60 & 72 & 9.2 & 72 & 4.1 & 45.3 & 87.2 & 4.2 & 48 & 1.7 & 18.8 & 79.2 \\
\hline 7 & Sucrase C & 15 & 5.0 & 60 & 72 & 10.0 & 96 & 4.1 & 45.3 & 80.4 & & & & & \\
\hline 8 & Sumizyme C & 10 & 4.5 & 50 & 72 & 5.0 & 48 & 2.1 & 23.2 & 82.2 & 5.6 & 48 & 1.8 & 19.9 & 62.9 \\
\hline
\end{tabular}

a) Saccharification and fermentation were performed at optimum temperature and $\mathrm{pH}$ of cellulase and yeast, respectively.

b) Time that yeast was added.

c) Time that the highest ethanol concentration was obtained after yeast was added.

d) Yield that based on the weight of NBKP used.

e) Yield that based on the weight of saccharified glucose.

f) After $48 \mathrm{~h}$ fermentation, the highest sugar concentration was obtained. 
Table 4 Successive saccharification and fermentation of alkali-treated NBKP with cellulase and yeast ${ }^{\mathrm{a}}$

\begin{tabular}{|c|c|c|c|c|c|c|c|c|c|c|c|c|c|c|c|}
\hline \multirow[t]{4}{*}{ No } & \multicolumn{5}{|c|}{ Saccharification } & \multicolumn{10}{|c|}{ Fermentation } \\
\hline & \multirow{2}{*}{\multicolumn{2}{|c|}{ Cellulase }} & \multirow{3}{*}{$\mathrm{pH}$} & \multirow{3}{*}{$\begin{array}{c}\text { Temp } \\
{ }^{\circ} \mathrm{C}\end{array}$} & \multirow{3}{*}{$\begin{array}{c}\text { Time }^{b} \\
h\end{array}$} & \multicolumn{5}{|c|}{ pYBGA1 } & \multicolumn{5}{|c|}{ K7 } \\
\hline & & & & & & Sugar & Time $^{c}$ & Ethanol & Yield $^{\mathrm{d}}$ & Yield $^{\mathrm{e}}$ & Sugar & Time & Ethanol & Yield $^{d}$ & Yield $^{\mathrm{e}}$ \\
\hline & & $\mathrm{wt} \%$ & & & & & $\mathrm{~h}$ & $\mathrm{~g} / \mathrm{L}$ & $\%$ & $\%$ & $\mathrm{~g} / \mathrm{L}$ & $\mathrm{h}$ & $\mathrm{g} / \mathrm{L}$ & $\%$ & $\%$ \\
\hline 1 & \multirow[t]{3}{*}{ Cellic CTec2 } & 10 & 4.5 & 45 & 72 & 12.8 & 24 & 6.1 & 69.7 & 93.3 & \multirow[t]{3}{*}{12.4} & 24 & 2.5 & 28.6 & 39.4 \\
\hline 2 & & & & & & & & & & & & 72 & 1.6 & 18.3 & 25.3 \\
\hline 3 & & 15 & 4.5 & 45 & 72 & 13.9 & 72 & 4.9 & 48.9 & 93.8 & & & & & \\
\hline 4 & \multirow[t]{3}{*}{ Meicelase } & 10 & 4.5 & 45 & 72 & 10.6 & 96 & 4.8 & 55.4 & 89.3 & \multirow[t]{3}{*}{13.5} & 24 & 5.1 & 58.4 & 73.9 \\
\hline 5 & & & & & & & & & & & & 72 & 1.8 & 20.6 & 26.1 \\
\hline 6 & & 15 & 4.5 & 45 & 72 & 15.7 & 48 & 6.9 & 78.9 & 86.1 & & & & & \\
\hline 7 & \multirow[t]{3}{*}{ Sucrase C } & 10 & 5.0 & 60 & 72 & 10.4 & 96 & 4.4 & 50.3 & 83.0 & \multirow[t]{3}{*}{15.2} & 24 & 1.2 & 13.7 & 15.4 \\
\hline 8 & & & & & & & & & & & & 72 & 0.4 & 4.6 & 5.1 \\
\hline 9 & & 15 & 5.0 & 60 & 72 & 15.0 & 96 & 7.4 & 84.7 & 96.7 & & & & & \\
\hline 10 & \multirow[t]{3}{*}{ Sumizyme C } & 10 & 4.5 & 50 & 72 & 10.0 & 120 & 5.0 & 57.2 & 98.0 & \multirow[t]{3}{*}{10.8} & 24 & 2.1 & 24.0 & 38.0 \\
\hline 11 & & & & & & & & & & & & 72 & 0.7 & 8.0 & 12.7 \\
\hline 12 & & 15 & 4.5 & 50 & 72 & 12.9 & 96 & 6.5 & 74.3 & 98.6 & & & & & \\
\hline
\end{tabular}

a) NBKP was treated with $9 \%$ aqueous $\mathrm{NaOH}$ solution for 10 min at $-9^{\circ} \mathrm{C}$.

b) Time that yeast was added.

c) Time that the highest ethanol concentration was obtained after yeast was added.

d) Yield that based on the weight of NBKP used.

e) Yield that based on the weight of saccharified glucose.

f) After $48 \mathrm{~h}$ fermentation, the highest sugar concentration was obtained.

was relatively effective for the saccharification of NBKP when compared to other combinations of cellulases and yeasts. As shown in No. 1, Cellic CTec2 was saccharified NBKP for $72 \mathrm{~h}$ to give $13.5 \mathrm{~g} / \mathrm{L}$ of glucose. Meicelase, Sucrase C, and Sumizyme C also gave $5.0-13.0 \mathrm{~g} / \mathrm{L}$ of glucose under their optimum conditions (Nos. 4-8). For fermentation, pYBGA 1 yeast was more effective than $\mathrm{K} 7$ yeast, a yeast for brewing of Japanese traditional alcohol (Sake). Based on the weight of saccharified glucose, ethanol was obtained in $85.7 \%-91.3 \%$ for pYBGA 1 yeast (Nos. 1-3) and $81.6 \%$ for $\mathrm{K} 7$ yeast. The reason why pYBGA 1 yeast is fermented effectively should be directly conversion of cello-oligosaccharides to ethanol. As the results, ethanol yields increased.

The SUSF of alkali-treated NBKP was also performed and the results are demonstrated in Table
4. All cellulases used resulted in a high amount of produced glucose after $72 \mathrm{~h}$ of saccharification. For alkali-treated NBKP, Cellic CTec2 (10 wt\%) also gave glucose in relatively high yields compared to other cellulases as shown in Nos. 1 and 3. However, when $15 \mathrm{wt} \%$ of cellulase was used, Meicelase and Sucrase $\mathrm{C}$ were found to work effectively and gave glucose in $15.7 \mathrm{~g} / \mathrm{L}$ (No. 6) and $15.0 \mathrm{~g} / \mathrm{L}$ (No. 9), respectively. Furthermore, ethanol was obtained at high yields by pYBGA 1 (Table 4). The crystallinity of cellulose in NBKP decreased because of alkali treatment, and cellulases produced glucose faster than untreated NBKP at short-time scales (Figure 1).

\subsection{Simultaneous saccharification and fermentation (SSF)}

Tables 5 and 6 were the results of the SSF method of NBKP and alkali-treated NBKP,

Table 5 Simultaneous saccharification and fermentation of NBKP with

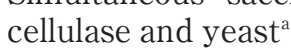

\begin{tabular}{|c|c|c|c|c|c|c|c|c|c|}
\hline \multirow{3}{*}{\multicolumn{2}{|c|}{ Cellulase }} & \multirow{4}{*}{$\mathrm{pH}$} & \multirow{4}{*}{$\begin{array}{c}\text { Temp } \\
{ }^{\circ} \mathrm{C}\end{array}$} & \multicolumn{6}{|c|}{ Ethanol conversion } \\
\hline & & & & \multicolumn{3}{|c|}{ pYBGA1 } & \multicolumn{3}{|c|}{ K7 } \\
\hline & & & & \multirow{2}{*}{$\begin{array}{c}\text { Time } \\
\mathrm{h}\end{array}$} & \multirow{2}{*}{$\begin{array}{c}\text { EtOH } \\
\mathrm{g} / \mathrm{L}\end{array}$} & \multirow{2}{*}{$\begin{array}{c}\text { Yield }^{\mathrm{b}} \\
\%\end{array}$} & \multirow{2}{*}{$\begin{array}{c}\text { Time } \\
\mathrm{h}\end{array}$} & \multirow{2}{*}{$\begin{array}{c}\text { EtOH } \\
\mathrm{g} / \mathrm{L}\end{array}$} & \multirow{2}{*}{$\begin{array}{c}\text { Yield }^{\mathrm{b}} \\
\%\end{array}$} \\
\hline & $\mathrm{wt} \%$ & & & & & & & & \\
\hline Cellic CTec2 & 10 & 4.5 & 30 & 72 & 4.0 & 44.2 & 96 & 3.0 & 33.1 \\
\hline Meicelase & 10 & 4.5 & 30 & 96 & 3.6 & 39.8 & 96 & 2.9 & 32.0 \\
\hline Sucrase C & 10 & 5.0 & 30 & 96 & 3.8 & 42.0 & 96 & 3.2 & 35.3 \\
\hline Sumizyme C & 10 & 4.5 & 30 & 72 & 4.0 & 44.2 & 72 & 2.1 & 23.2 \\
\hline
\end{tabular}

a) NBKP (20 g, cellulose content 88.3\%) was used.

b) Yield based on the weight of NBKP. 
Table 6 Simultaneous saccharification and fermentation of alkali-treated NBKP with cellulase and yeast ${ }^{a}$

\begin{tabular}{|c|c|c|c|c|c|c|c|c|c|}
\hline \multirow{3}{*}{\multicolumn{2}{|c|}{ Cellulase }} & \multirow{4}{*}{$\mathrm{pH}$} & \multirow{4}{*}{$\begin{array}{c}\text { Temp } \\
{ }^{\circ} \mathrm{C} \\
\end{array}$} & \multicolumn{6}{|c|}{ Ethanol conversion } \\
\hline & & & & \multirow{3}{*}{$\begin{array}{c}\text { Time } \\
\mathrm{h}\end{array}$} & \multicolumn{2}{|c|}{ pYBGA1 } & \multicolumn{3}{|c|}{$\mathrm{K} 7$} \\
\hline & & & & & $\mathrm{EtOH}$ & Yield $^{b}$ & Time & EtOH & Yield $^{b}$ \\
\hline & $\mathrm{wt} \%$ & & & & $\mathrm{~g} / \mathrm{L}$ & $\%^{\mathrm{c}}$ & $\mathrm{h}$ & $\mathrm{g} / \mathrm{L}$ & $\%^{\mathrm{c}}$ \\
\hline Cellic CTec2 & 10 & 4.5 & 30 & 48 & 5.6 & 64.4 & 96 & 5.2 & 59.8 \\
\hline Meicelase & 10 & 4.5 & 30 & 48 & 4.9 & 56.3 & 72 & 2.7 & 31.0 \\
\hline Sucrase C & 10 & 5.0 & 30 & 96 & 6.8 & 78.2 & 96 & 4.4 & 50.6 \\
\hline Sumizyme C & 10 & 4.5 & 30 & 72 & 6.1 & 70.1 & 96 & 4.5 & 51.7 \\
\hline
\end{tabular}

a) Alkali-treated NBKP (20 g, cellulose content $90.5 \%)$ was used.

b) Yield based on the weight of the alkali-treated NBKP.

respectively. In Table 5, ethanol from alkali-untreated NBKP was obtained in almost the same yields by the combinations of cellulases and pYBGA 1 yeast. In Table 6, when alkali-treated NBKP was used, it was found that the combinations of Sucrase $\mathrm{C}$ and Sumizyme C cellulases with pYBGA 1 yeast (Nos. 3 and 4), respectively, produced ethanol in higher yields than the combination of Cellic CTec2 and Meicelase cellulases with pYBGA 1 yeast (Nos. 1 and 2). The fermentation with pYBGA 1 yeast was more effective than $\mathrm{K} 7$ yeast for the SSF method and ethanol was obtained in relatively higher yields from alkali-treated NBKP (Table 6) in comparison with untreated NBKP (Table 5). However, the yield of ethanol was lower than that of SUSF and the reason is because both saccharification and fermentation in the SSF method were conducted under the optimal conditions of yeasts (typical conditions for the fermentation step). Thus, the fermentation conditions may not have been optimal for cellulases to function efficiently during the saccharification process.

\section{Conclusions}

Successive saccharification and fermentation (SUSF) of NBKP produced bioethanol at good yields. After $72 \mathrm{~h}$ saccharification of $20 \mathrm{~g} / \mathrm{L}$ of NBKP with Cellic CTec2 (10 wt\% compared to NBKP) as a commercially available cellulase at $\mathrm{pH} 4.5$ and $45^{\circ} \mathrm{C}$ and then a recombinant yeast, pYBGA $1\left(1 \times 10^{8}\right.$ cells/ $\mathrm{mL}$ ), was added at $\mathrm{pH} 5.0$ and $30^{\circ} \mathrm{C}$. It was found that bioethanol could be produced at a yield of $91.3 \%$, based on saccharified glucose, via SUSF. Alkalitreated NBKP could result in bioethanol produced at a yield of $93.3 \%$, also via SUSF. Simultaneous saccharification and fermentation (SSF) of NBKP afforded lower yields of bioethanol than those obtained via the SUSF method; this may be because the SUSF method allowed each step to proceed under its optimum conditions. This paper described a convenient method to produce bioethanol from NBKP by combining commercially available cellulases and recombinant yeasts (e.g., Cellic CTec2 and pYBGA 1). Further investigations of bioethanol production from cellulosic materials are in progress.

\section{References and Notes}

1. C. E. Wyman, Ed, Handbook of bioethanol. Taylor \& Francis, Washington DC (1996).

2. C. Laluce, A. C. G. Schenberg, J. C. M. Gallardo, L. F. C. Coradello and S. R. Pombeiro-Sponchiado, "Advances and developments in strategies to improve strains of Saccharomyces cerevisiae and processes to obtain the lignocellulosic ethanol-a review”, Appl. Biochem. Biotechnol., 166, 1908-1926 (2012).

3. D. Chiaramonti, M. Prussi, S. Ferrero, L. Oriani, P. Ottonello, P. Torre and F. Cherchi, "Review of pretreatment processes for lignocellulosic ethanol production, and development of an innovative method", Biomass Bioener., 46, 25-35 (2012).

4. T. Uryu, M. Sugie, S. Ishida, S. Konoma, H. Kato, K. Katsuraya, K. Okuyama, G. Borjihan, K. Iwashita and H. Iefuji, "Chemo-enzymatic production of fuel ethanol from cellilosic materials utilizing yeast expressing beta-glucosidases", Appl. Biochem. Biotecnol., 135, 15-31 (2006).

5. X. Liang, T. Yoshida and T. Uryu, "Direct saccharification and ethanol fermentation of cellooligosaccharides with recombinant yeast", Carbohydr. Polym., 91, 157-161 (2013).

6. X. Zhao, X. Liang, S. Han, T. Uryu and T. Yoshida, "Successive saccharification and fermentation of cellulosic agricultural residues using a combination of cellulase and recombinant yeast", 
Sen’i Gakkai-shi, 70, 191-196 (2014).

7. V. Gehmayr and H. Sixta, "Pulp properties and their influence on enzymatic degradability", Biomacromolecules, 13, 645-651 (2012).

8. H. Nonaka and R. Sakai, "Effect of beating on enzymatic saccharification of wood pulp", $J$. Jpn. Inst. Energy, 92, 1187-1190 (2013).

9. N. A. Bauer and W. R. Gibbons, "Saccharification versus simultaneous saccharification and fermentation of Kraft pulp", Int. j. Biol. Eng., 5, 4855 (2012).

10. M. Monrroy, J. R. Garcia, R. T. Menconca, J. Baeza and J. Freer, "Kraft pulp of Eucalyptus globulus as a pretreatment for bioethanol production by simultaneous saccharification and fermentation", J. Chil. Chem. Soc., 57, 1113-1117 (2012).

11. L. Kang, W. Wang and Y. Y. Lee, "Bioconversion of Kraft paper mill sludges to ethanol by SSF and SSCF”, Appl. Biochem. Biotechnol., 161, 53-66 (2010)

12. K. Iwashita, K. Todoroki, H. Kimura, H. Shimoi and K. Ito, "The bglA gene of Aspergillus kawachii encodes both extracellular and cell wallbound glucosidases", Biosci. Biotechnol. Biochem., 62, 1938-1946 (1998).

13. K. Kamide, Y. Yasuda, T. Matsui, K. Okajima and T. Yamashita, "Structural change in alkali soluble cellulose solid during its dissolution into aqueous alkaline solution”, Cell. Chem. Tech., 24, 23-37 (1990).
14. K. Kamide, K. Okajima and K. Kowsaka, "Disolution of natural cellulose into aqueous alkali solution Role of super-molecular structure of cellulose”, Polym. J., 24, 71-86 (1992).

15. A. Sluiter, B. Hames, R. Ruiz, C. Scarlata, J., Sluiter, D. Templeton and D. Crocker, "Determination of structural carbohydrates and lignin in biomass", Tech. Report National Renewable Energy, Laboratory, http://www.nrel.gov/biomass /pdfs/42618 (2011).

16. H. Kawaguchi, K. Uematsu, C. Ogino, H. Teramura, S. Nakamura, Y. Tsuge, T. Hasunuma, K. Oinuma, N. Takaya and A. Kondo, "Simultaneous saccharification and fermentation of Kraft pulp by recombinant Eschericia coli for phenyllactic acid production”, Int. J. Agricl. Biol. Eng., 5, 48-55 (2012).

17. N. A. Bauer and W. R. Gibbons, "Saccharification versus simultaneous saccharification and fermentation of Kraft pulp”, Biochem. Eng. J., 88. 188-194 (2014).

18. E. Hult, P. T. Larsson and T. Iversen, "A comparative $\mathrm{CP} / \mathrm{MAS}{ }^{13} \mathrm{C}$-NMR study of cellulose structure in spruce wood and Kraft pulp", Cellulose, 7, 35-55 (2000).

19. O. A. Wuorinen and A. Vianpaa, "X-ray diffractometric method for the determination of the crystallinity of cellulose”, Nerelco Report, 9, 4852 (1962). 